Original Article

\title{
THE METHANOLIC EXTRACT OF MIMOSA PIGRA LEAVES REDUCES THE SEVERITY OF DIARRHEA AS WELL AS INHIBITS THE GROWTH OF DIARRHEA-CAUSING BACTERIA
}

\author{
MST. HAJERA KHATUN ${ }^{*}$, JAYTIRMOY BARMON ${ }^{1}$, SIMIN SHABNAM LOPA ${ }^{1}$, MD. MANIRUZZAMAN ${ }^{1}$, MD. ROBIUL \\ ISLAM1 1 , AL MAMUN ${ }^{2}$
}

${ }^{1}$ Department of Pharmacy, Varendra University, Rajshahi 6204, Bangladesh, ${ }^{2}$ Department of Pharmacy, University of Rajshahi, Rajshahi 6205, Bangladesh

Email: hajera@vu.edu.bd

Received: 19 Nov 2021, Revised and Accepted: 22 Jan 2022

ABSTRACT

Objective: Diarrhea is a major global health issue that has become increasingly prevalent in developing countries. In Bangladesh, Mimosa pigra L. is used traditionally for the treatment of diarrhea and also to control infection. Our main objective was to evaluate whether the methanolic extract of Mimosa pigra (MEMP) leaves has the antidiarrheal effect as well as the antibacterial effect against diarrhea-causing bacteria.

Methods: The antibacterial potentialities of MEMP leaves were investigated by the disc diffusion method against six Gram-positive and six Gramnegative bacteria at $500 \mu \mathrm{g} /$ disc. Kanamycin $(30 \mu \mathrm{g} / \mathrm{disc})$ was used as the standard drug. Antidiarrheal activities of leaf extracts were determined at two doses $(200$ and $400 \mathrm{mg} / \mathrm{kg}$ ) in a castor oil and magnesium sulfate-induced diarrheal model in mice. The results were evaluated by One-Way Analysis of Variance (ANOVA) followed by Dunnet's test. ${ }^{* *} \mathrm{P}<0.01$ and ${ }^{* * *} \mathrm{P}<0.001$ were considered significant compared to control.

Results: The MEMP leaves exhibited moderate to potent antimicrobial activity with the zone of inhibition range 11 to $17 \mathrm{~mm}$ against diarrhea causing bacteria such as Salmonella paratyphi $(16.33 \mathrm{~mm})$, Salmonella typhi $(17 \mathrm{~mm})$, Shigella boydii $(12 \mathrm{~mm})$, Shigella dysenteriae $(12.67 \mathrm{~mm})$ and Escherichia coli $(11 \mathrm{~mm})$. Furthermore the severity of diarrhea was significantly reduced $(\mathrm{P}<0.001)$ by MEMP leaves at a dose of $400 \mathrm{mg} / \mathrm{kg}$ $(13 \pm 2.16)$ compared to control $(30.25 \pm 2.87)$ by castor oil-induced method. The same dose of the extract also significantly inhibited $(\mathrm{P}<0.01)$ the severity of diarrhea $(14.75 \pm 1.71)$ compared to control $(24 \pm 2.16)$ by magnesium sulfate-induced diarrheal model. The percent inhibition of diarrhea in $3 \mathrm{~h}$ by MEMP leaves at a dose of $400 \mathrm{mg} / \mathrm{kg}$ was $57.02 \%$ and $38.54 \%$ in castor oil and magnesium sulfate-induced diarrheal model, respectively.

Conclusion: Confirmed findings in this study naturally suggested that MEMP leaves could be an effective antibacterial and antidiarrheal formulation.

Keywords: Antimicrobial, Antidiarrheal, Disk diffusion, Castor oil, Mimosa pigra leaves

(C) 2022 The Authors. Published by Innovare Academic Sciences Pvt Ltd. This is an open-access article under the CC BY license (https://creativecommons.org/licenses/by/4.0/) DOI: https://dx.doi.org/10.22159/ijpps.2022v14i3.43603. Journal homepage: https://innovareacademics.in/journals/index.php/ijpps.

\section{INTRODUCTION}

Diarrhea is generally defined as the passage of abnormally liquid or unformed stools associated with increased frequency of defecation and abdominal pain [1]. During diarrhea, the normal bowel movement becomes changed, which results in an increase in water content, volume, or frequency of the stools [2]. According to the World Health Organization (WHO), diarrhea is the second leading reason of death of children less than five years of age [3]. Despite reductions in morbidity and mortality worldwide, diarrhea still accounts for more than 2 million deaths of children less than 5 y of age annually and is associated with impaired physical and cognitive development in resource-limited countries $[4,5]$. Of all child deaths from diarrhea, $78 \%$ occur in the African and South-East Asian regions, creating a tremendous economic strain on healthcare costs [6]. The common reason for causing diarrhea is gastrointestinal infection by various types of bacteria, virus, and parasites $[7,8]$. This infection can be spread out through food, drinking water, and an unhygienic environment [9]. Along with improvements in living standards and health conditions, the incidence of parasite infections has decreased, with viruses and bacteria now being predominantly responsible for acute diarrhea in children $[8,9]$. Most reports worldwide agree that rotavirus is the primary cause of acute diarrhea in children [10-12]. However, the etiology of bacteria causing diarrhea appears to differ depending on geographical area. In Bangladesh, Campylobacter, enteropathogenic E. coli, Shigella spp. and Salmonella spp were the most frequent probable contributors to acute diarrhea in children [13]

Many people who get diarrhea suddenly have a self-limiting sickness that does not require treatment. Dehydration and electrolyte imbalance are the main dangers in severe cases, especially in newborns, children, and the elderly, necessitating both nonpharmacological and pharmacological treatments, such as oral rehydration therapy (ORT) and zinc supplements [4]. Antimicrobial agents reduce the severity and duration of infectious diarrhea. However, antimicrobials can have side effects, and bacteria are increasingly developing resistance to them. As a result, the hunt for safer and more effective plant-based drugs has remained a focus of active research. Medicinal plants could be potential source of antidiarrheal medicines in the treatment of diarrhea [14]. Furthermore, numerous international organizations, such as the World Health Organization (WHO), have encouraged for research on the treatment and prevention of diarrheal diseases utilizing traditional medical practices $[15,16]$. Around $25 \%$ of medications are now derived from plants, and there is a wealth of research on the usage of medicinal plants, including their pharmacological and biochemical qualities [17]

Mimosa pigra L. (commonly known as giant sensitive plant, bush plant, catclaw mimosa or black mimosa) belongs to the subfamily Mimosoideae, in the lager family Fabaceae of legumes (Leguminosae) [18]. It is native to tropical America and naturalized in tropical Asia. M. pigra L. is invasive, especially in parts of South East Asia and Australia [19]. M. pigra is closely related to Mimosa pudica (common sensitive plant). It can be distinguished from Mimosa pudica by its large size, large pods ( 6 to $8 \mathrm{~cm}$ long as opposed to $2.5 \mathrm{~cm}$ long) and leaves, which have 6 to 16 pairs of pinnae as opposed to 1 to 2 pairs on $M$. pudica leaves [18]. M. pigra L. is a traditional treatment for asthma, diarrhea, typhoid fever, genitourinary tract infections, snakebite, weak heart or weak pulse, hyperglycemia and also for its antimicrobial activity [18-20]. Several researches have been confirmed its antihypertensive, anticancer, antihyperglycemic, antiasthmatic, antinociceptive and antimicrobial activity [18-22]: 
With a view to find the pharmacological rationale for some of the reports and traditional uses of the plant, the present investigation was undertaken to explore whether the methanolic extract of $M$. pigra (MEMP) leaves has antidiarrheal and antibacterial activity.

\section{MATERIALS AND METHODS}

\section{Plant material}

Fresh M. pigra leaves were collected from the Bandorban area of Bangladesh, and were identified by experts at the Bangladesh National Herbarium in Dhaka, whose voucher specimen no. is 29663. The collected plant parts were sun-dried for one week and pulverized into a coarse powder with the help of a suitable grinder. Until the analysis, the powder was stored in an airtight container and kept in a cool, dark, and dry place.

\section{Preparation of the extract}

MEMP leaves was prepared according to the previously described method with slight modification [23]. Briefly about $150 \mathrm{gm}$ of powdered material was taken in a clean, flat bottomed glass container and soaked in $200 \mathrm{ml}$ of $85 \%$ methanol. The container with its contents was sealed and kept for a period of $7 \mathrm{~d}$ accompanying occasional shaking and stirring. The whole mixture then underwent a coarse filtration by a piece of clean, white cotton material. Then it was filtered through Whatman filter paper (Bibby RE200, Sterilin Ltd.,UK). The filtrate obtained (methanol extract) was evaporated using rotary evaporator. It rendered a gummy concentrate of reddish black color. The gummy concentrate was designated as crude extract of methanol. The extract was transferred to a closed container for further use and protection.

\section{Preliminary phytochemical screening}

Standard tests were employed to detect the major secondary metabolites such as phenolic compounds, saponins, flavonoids, tannins, sterols, alkaloids, cardiac glycosides, and terpenoids [24, 25].

\section{Microorganisms and media}

The test microorganisms used in this study were six Gram-positive and six Gram negative bacteria (table 2). The microorganisms were collected as pure cultures from the Microbiology Laboratory, Department of Pharmacy, University of Rajshahi, Bangladesh. The bacterial isolates were first sub-cultured in a nutrient agar medium and incubated at $37^{\circ} \mathrm{C}$ for 18 .

\section{Animals}

In the present study, Swiss albino mice (male), which weighed between 20-25 g were used. The animals were obtained from the International Centre for Diarrheal Disease Research, Bangladesh (ICDDRB). After their purchase, the mice were kept in standard environmental conditions $\left(24.0 \pm 0{ }^{\circ} \mathrm{C}\right.$ and $55-65 \%$ relative humidity and $12 \mathrm{~h}$ light/dark cycle) for one week to acclimate and fed ICDDRB formulated rodent food and water adlibitum. The animals were acclimatized for one week prior to actual experiments. The study was conducted following approval by the Institutional Animal Ethical Committee of Varendra University, Rajshahi, Bangladesh.

\section{Acute toxicity test}

Animals were divided into five groups ( $n=6$ per group) which were administered different doses of the crude extract $(31.25,62.5,125$, $250,500,1000$ and $2000 \mathrm{mg} / \mathrm{kg}$ p. o.), while the control group received only the vehicle ( $1 \%$ Tween 80 in water, p. o.). The general signs and symptoms of toxicity were observed for $24 \mathrm{~h}$ and mortality was recorded for each group at the end of this period [26].

\section{Antibacterial assay}

The methanol crude extract of the plant was examined for its antibacterial activity by the disc diffusion method [27]. Solutions of known concentration $(50 \mathrm{mg} / \mathrm{ml}$ ) of the test samples were prepared by dissolving measured amounts of samples in calculated solvent volumes. Dried and sterilized filter paper discs (5 mm diameter) were then impregnated with $10 \mu \mathrm{l}$ of the test substance using a micropipette and allowed to dry off the solvent in an aseptic hood. Thus, such discs contain $500 \mu \mathrm{g}$ of crude extract. Discs containing the test material were placed on a nutrient agar medium (Merck) uniformly seeded with the pathogenic test microorganisms. The prepared inoculum size was approximately $10^{6} \mathrm{cfu} / \mathrm{ml}$. Standard antibiotic discs (kanamycin, $30 \mu \mathrm{g} / \mathrm{disc}$ ) and blank discs (impregnated with solvents) were used as positive and negative controls, respectively. These plates were then, kept at $4{ }^{\circ} \mathrm{C}$ for a $1-\mathrm{h}$ diffusion of the test material. There was a gradual change in concentration surrounding the discs. The plates were then incubated at $37^{\circ} \mathrm{C}$ for $24 \mathrm{~h}$ to allow organism growth. The test materials having antibacterial activity inhibited microorganism growth, and a clear, distinct zone of inhibition surrounding the discs was visualized. The antibacterial activity of the test agents was determined by measuring the diameter of the zone of inhibition expressed in millimetres.

\section{In vivo antidiarrheal activity}

\section{Castor oil-induced diarrhea}

The experiment was performed according to the method previously described [28]. Briefly, mice fasted for $24 \mathrm{~h}$ randomly allocated to four groups of four animals each. The animals were all screened initially by giving $0.5 \mathrm{ml}$ of castor oil. Only those showing diarrhea was selected for the final experiment. The group I (Normal control) received $1 \%$ tween 80 in water $(10 \mathrm{ml} / \mathrm{kg}$, p. o.), Group II (standard control) was given antidiarrheal drug loperamide $(5 \mathrm{mg} / \mathrm{kg}, \mathrm{p}$. o.) in suspension and groups III and IV received p. o. the drug extract (200 and $400 \mathrm{mg} / \mathrm{kg}$ ) respectively. After $60 \mathrm{~min}$, each animal was given $0.5 \mathrm{ml}$ of castor oil, each animal was placed in an individual cage, the floor of which lined with blotting paper for observation of the number and consistency of fecal droppings. The numbers of both wet and dry droppings were counted every $30 \mathrm{~min}$ for $3 \mathrm{~h}$, and the white paper was changed after each evaluation. The means of the stools passed by the treated groups were compared with that of the control group. The mean number of diarrheic feces pooled by the control group was considered as $100 \%$. The level of inhibition (\%) of defecation caused by extracts was calculated relative to the control using the following relationship: Inhibition of defecation $(\%)=$ $[(\mathrm{NDC}-\mathrm{NDT}) / \mathrm{NDC}] \times 100$; where NDC $=$ mean number of diarrheic feces of the control group; NDT $=$ mean number of diarrheic feces of the treated group.

\section{Magnesium sulfate-induced diarrhea}

Diarrhea was induced by oral administration of magnesium sulfate at the dose of $2 \mathrm{~g} / \mathrm{kg}$ to the animals $30 \mathrm{~min}$ after pretreatment with vehicle $(1 \%$ Tween 80 in water, $10 \mathrm{ml} / \mathrm{kg}$, p. o.) to the control group, loperamide $(5 \mathrm{mg} / \mathrm{kg})$ to the positive control group, and the methanol extract at the doses of 200 and $400 \mathrm{mg} / \mathrm{kg}$ to the test groups [29]. The level of inhibition (\%) of defecation caused by extracts was calculated relative to the control using the following relationship: Inhibition of defecation $(\%)=[($ NDC-NDT) $/ N D C] \times 100$; where NDC = mean number of diarrhoeic faeces of the control group; NDT = mean number of diarrheic feces of the treated group.

\section{RESULTS}

\section{Phytochemical study}

The result of preliminary phytochemical screening of the MEMP leaves is presented in table 1 and it revealed that the extract contains flavonoids, alkaloids, terpenoids, phenols, saponins, and tannins, whereas cardiac glycosides and sterols were absent.

Table 1: List of phytochemicals present in MEMP

\begin{tabular}{lll}
\hline S. No. & Phytochemicals & MEMP \\
\hline 1. & Terpenoids & + \\
2. & Flavonoids & + \\
3. & Tannins & + \\
4. & Phenols & + \\
5. & Cardiac Glycosides & - \\
6. & Saponins & + \\
7. & Alkaloids & + \\
8. & Sterols & - \\
\hline
\end{tabular}

$(+)$ present, (-) absent. 


\section{Acute toxicity test}

No lethal effects were observed within $24 \mathrm{~h}$ after the administration of the extract at any of the doses used, even at the highest dose tested $(2000 \mathrm{mg} / \mathrm{kg})$. Therefore, the lethal dose $\left(\mathrm{LD}_{50}\right)$ of the extract in mice could not be determined.

\section{Antibacterial activity}

Evaluation of the antimicrobial activity of MEMP was determined by the disc diffusion method against six Gram-positive (Bacillus megaterium, Bacillus subtilis, Staphylococcus aureus, Sarcina lutea, Bacillus anthracis, Bacillus cereus) and six Gram-negative
(Escherichia coli, Pseudomonas aeruginosa, Salmonella paratyphi, Salmonella typhi, Shigella boydii, Shigella dysenteriae) bacteria.

These organisms were frequently encountered in infectious diseases. The study showed that the plant extract used in the study exhibited a varying degree of antimicrobial activity against all microorganisms tested (table 2). The extract exhibited potent to moderate inhibitory activity with the zone of inhibition range 8.33 to $17 \mathrm{~mm}$. The highest activity was observed against Salmonella typhi $(17 \mathrm{~mm})$ followed by Salmonella paratyphi (16.33 mm), Bacillus anthracis $(14.67 \mathrm{~mm})$, Bacillus cereus (13.32 mm), Shigella dysenteriae (12.63 mm), Shigella boydii (12 $\mathrm{mm})$ and Escherichia coli $(11 \mathrm{~mm})$.

Table 2: Antibacterial activity of MEMP

\begin{tabular}{lll}
\hline & Diameter of zone of inhibition (mm) & Kanamycin Disc (30 ug/disc) \\
\hline Bacterial strain & MEMP (500 ug/disc) & $25.17 \pm 0.76$ \\
\hline Gram positive & & $23.17 \pm 0.76$ \\
Bacillus megaterium & $8.33 \pm 1.52$ & $29.5 \pm 0.5$ \\
Bacillus subtilis & $10.17 \pm 1.04$ & $25.17 \pm 1.04$ \\
Staphylococcus aureus & $11.5 \pm 1.32$ & $24.67 \pm 0.76$ \\
Sarcina lutea & $12 \pm 2.00$ & $29.33 \pm 1.04$ \\
Bacillus anthracis & $14.67 \pm 1.52$ & $23 \pm 1.00$ \\
Bacillus cereus & $13.32 \pm 1.52$ & $22.33 \pm 1.52$ \\
Gram Negative & & $25 \pm 1.00$ \\
Escherichia coli & $11 \pm 1.00$ & $24.17 \pm 1.26$ \\
Pseudomonas aeruginosa & $9.33 \pm 1.52$ & $23.5 \pm 0.71$ \\
Salmonella paratyphi & $16.33 \pm 1.53$ & $19.83 \pm 1.76$ \\
Salmonella typhi & $17 \pm 2.00$ & $12 \pm 1.00$ \\
Shigella boydii & $12.67 \pm 1.15$ & \\
Shigella dysenteriae & & \\
\hline
\end{tabular}

Assay was performed in triplicate and the results are the mean of three values \pm standard deviation

\section{Antidiarrheal activity}

\section{Castor oil-induced diarrheal method}

In the castor oil-induced diarrhea, MEMP leaves (200 and 400 $\mathrm{mg} / \mathrm{kg}$ ) reduced the number of faeces in a dose-dependent manner (fig. 1a). These results of both doses were statistically significant $(\mathrm{P}<0.001)$. After a 30 -min administration of castor oil diarrhea was clinically apparent for the next $3 \mathrm{~h}$ in the control group. This condition was markedly reduced to $57.02 \%$ by MEMP at a dose of $400 \mathrm{mg} / \mathrm{kg}$, which was the same as the percent inhibition $(57.02 \%)$ of the standard drug loperamide at a dose of $5 \mathrm{mg} / \mathrm{kg}$ (fig. 1b).

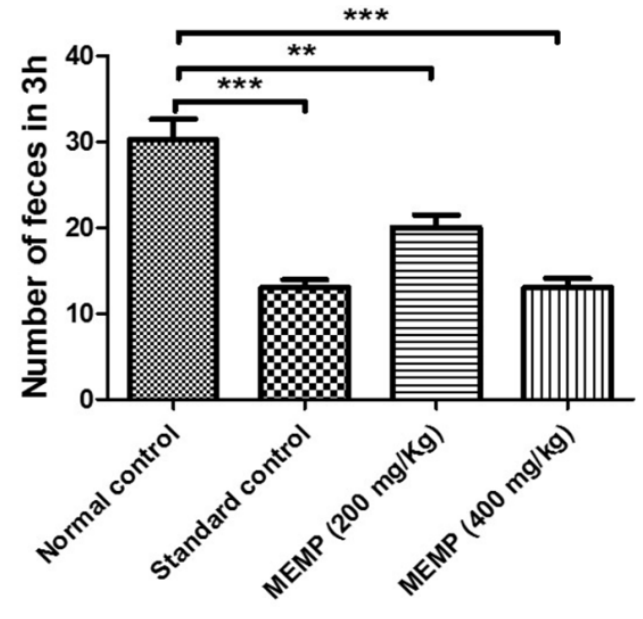

a

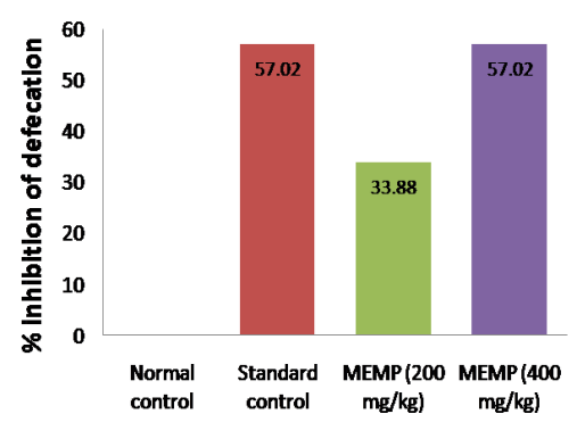

Fig. 1: Effect of MEMP on castor oil-induced diarrhea in mice, a) Values are presented as mean \pm SEM, ( $n=5$ ); 0 ene-way analysis of variance (ANOVA) followed by dunnet's test. ${ }^{* *} \mathrm{P}<0.01$ and ${ }^{* * *} \mathrm{P}<0.001$, significant compared to control. b) Percent inhibition of diarrhea by MEMP

\section{Magnesium sulfate-induced diarrheal method}

The extract reduced the number of diarrhea induced by magnesium sulfate (fig. 2a). The extract at a dose of $400 \mathrm{mg} / \mathrm{kg}$ has shown a significant $(\mathrm{P}<0.01)$ reduction of the number of diarrhea in $3 \mathrm{~h}$. The percent inhibition of diarrhea was $45.83 \%$ by standard drug loperamide, whereas the extract showed $38.54 \%$ inhibition of diarrhea at a dose of $400 \mathrm{mg} / \mathrm{kg}$. 


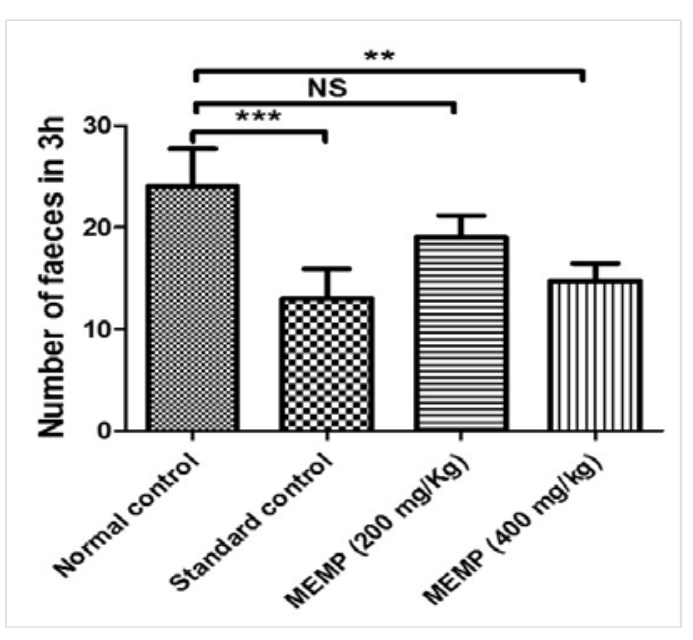

a

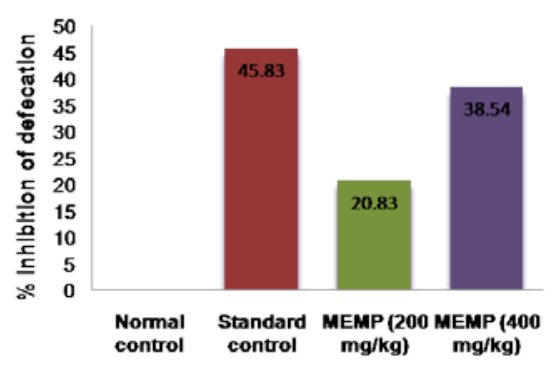

Fig. 2: Effect of MEMP on magnesium sulfate-induced diarrhea in mice, a) Values are presented as mean \pm SEM, (n=5); One-Way Analysis of Variance (ANOVA) followed by Dunnet's test. ${ }^{* *} \mathrm{P}<0.01$ and ${ }^{* * *} \mathrm{P}<0.001$, significant compared to control. b) Percent inhibition of diarrhea by MEMP

\section{DISCUSSION}

Antibacterial agents are chemicals, either synthetic or natural, that interfere with the growth and reproduction of bacteria. But several pathogenic bacteria have acquired antibiotic resistance. The use of commercial antimicrobial drugs at random or in an unsuitable manner has resulted in antibiotic resistance. Synthetic antibiotics have also been linked to the development of some side effects such as skin irritation, organ damage, and immune hypersensitivity [30]. This has necessitated a search for a new source of antimicrobial substances from plants as they produce a variety of bioactive compounds of known therapeutic properties.

The present study sought to assess the antidiarrheal and antimicrobial activity of the MEMP leaves. The results of the study showed that the MEMP produced a statistically significant reduction in the severity of diarrhea produced by castor oil and magnesium sulfate. It is also noted that the extract had activity against diarrhea causing bacteria such as Salmonella paratyphi, Salmonella typhi, Shigella boydii, Shigella dysenteriae and Escherichia coli.

Numerous reports confirmed that castor oil-induced diarrheal action [29]. Castor oil's ability to cause diarrhea by inducing a hypersecretory reaction due to its most active component, recinoleic acid, has been demonstrated [28, 29]. This acid irritates and inflames the intestinal mucosa, causing the release of inflammatory mediators including prostaglandins, histamine, and nitric oxide, which induces gastrointestinal motility, secretions, epithelial permeability, and edema of the intestinal mucosa, thereby inhibiting $\mathrm{Na}+, \mathrm{K}+$, and water re-absorption $[30,31]$. In this study, MEMP leaves $(200$ and $400 \mathrm{mg} / \mathrm{kg}$ ) reduced the number of cases of diarrhea caused by castor oil, and this decreasing capacity could be due to its antisecretory function. Magnesium sulphate, on the other hand, has been found to produce diarrhea by raising intestinal content and blocking water reabsorption [28]. Moreover, it promotes the liberation of cholecystokinin from the duodenal mucosa, which increases the secretion and motility of small intestine and thereby prevents the reabsorption of sodium chloride and water [32]. In magnesium sulphate diarrheal test, the extract alleviated the diarrheal condition and $400 \mathrm{mg} / \mathrm{kg}$ dose extract showed a significant reduction of diarrhea compared to the control group. As the extract delayed gastrointestinal transit in mice relative to the control, it may have boosted water and electrolyte absorption from the gastrointestinal tract.

The phytochemical analysis of the extract revealed the presence of different bioactive agents such as flavonoids, alkaloids, terpenoids, phenols, saponins, and tannins. Among them, flavonoids and alkaloids are known to suppress prostaglandin production via altering the production of cyclooxygenase 1 and 2 (COX-1, COX-2) and lipoxygenase (LOX) [33, 34]. Tannins in the extract make the intestinal mucosa more resistant to chemical changes, resulting in fewer peristaltic movements and less intestinal secretion [35].

The flavonoids, alkaloids, and tannins in the extract may therefore account for the antidiarrheal effect of MEMP leaves demonstrated in this study. Furthermore, alkaloids, saponins, tannins, flavonoids and phenols have been attributed for the antimicrobial activity of the extract [36]. The antibacterial effectiveness of tannins is explained by their ability to pass through the bacterial cell wall up to the internal membrane, interference with the metabolism of the cell, and as a result of their destruction [37]. However, the mechanism of action of the secondary metabolites was not evaluated in the present study.

Although the previous studies reported the antibacterial activity of Mimosa pigra [22], this is the first report of antidiarrheal activity of MEMP leaves to the best of our knowledge. Moreover, our study demonstrated the antidiarrheal activity against major diarrhea causing bacteria such as Salmonella paratyphi, Salmonella typhi, Shigella boydii, Shigella dysenteriae and Escherichia coli. that are prevalent in Bangladesh.

\section{CONCLUSION}

We can conclude from the study's findings that MEMP leaves significantly reduces the severity of diarrhea in mice, as well as inhibits the growth of diarrhea-causing bacteria. However, to discover the active principles and exact mechanisms of action, more bioassay-guided phytochemical and pharmacological researches are needed.

\section{ACKNOWLEDGEMENT}

The authors gratefully acknowledge Microbiology laboratoty at Department of Pharmacy, University of Rajshahi for providing the fresh culture of bacteria. The authors also express the heartiest gratitude to Square Pharmaceuticals Ltd., Bangladesh for providing loperamide.

\section{AUTHORS CONTRIBUTIONS}

Mst. Hajera Khatun designed and performed the research, analyzed the data and wrote the manuscript. Jaytirmoy Barmon analyzed the data and wrote the manuscript, Simin Shabnam Lopa and Md. Maniruzzaman edited the manuscript, Md. Robiul Islam performed the research, Al Mamun performed the research, analyzed the data and reviewed the manuscript. All authors have read and agreed to the published version of the manuscript. 


\section{CONFLICT OF INTERESTS}

The authors declare that they have no conflict of interest.

\section{REFERENCES}

1. Birru EM, Asrie AB, Adinew GM, Tsegaw A. Antidiarrheal activity of crude methanolic root extract of Idigofera spicata Forssk.(Fabaceae). BMC Complement Altern Med. 2016 Aug 5;16:272. doi: 10.1186/s12906-016-1252-4, PMID 27492007.

2. Sharma P, Vidyasagar G, Singh S, Ghule S, Kumar B. Antidiarrhoeal activity of leaf extract of Celosia argentea in experimentally induced diarrhoea in rats. J Adv Pharm Technol Res. 2010 Jan;1(1):41-8. PMID 22247831.

3. Rahman MK, Chowdhury MA, Islam MT, Chowdhury MA, Uddin ME, Sumi CD. Evaluation of antidiarrheal activity of methanolic extract of Maranta arundinacea Linn. leaves. Adv Pharmacol Sci. 2015;2015:257057. doi: 10.1155/2015/257057, PMID 26346095.

4. Mekonnen B, Asrie AB, Wubneh ZB. Antidiarrheal activity of $80 \%$ methanolic leaf extract of Justicia schimperiana. Evid Based Complement Alternat Med. 2018 Feb 6;2018:3037120. doi: 10.1155/2018/3037120, PMID 29541140.

5. Mehmood MH, Siddiqi HS, Gilani AH. The antidiarrheal and spasmolytic activities of phyllanthus emblica are mediated through dual blockade of muscarinic receptors and Ca2+channels. J Ethnopharmacol. 2011 Jan 27;133(2):856-65. doi: 10.1016/j.jep.2010.11.023. PMID 21093572.

6. Boschi Pinto C, Velebit L, Shibuya K. Estimating child mortality due to diarrhoea in developing countries. Bull World Health Organ. 2008 Sep;86(9):710-7. doi: 10.2471/blt.07.050054, PMID 18797647.

7. Tian L, Zhu X, Chen Z, Liu W, Li S, Yu W, Zhang W, Xiang X, Sun Z. Characteristics of bacterial pathogens associated with acute diarrhea in children under 5 years of age: a hospital-based cross-sectional study. BMC Infect Dis. 2016 Jun 7;16:253. doi: 10.1186/s12879-016-1603-2, PMID 27267601.

8. Kotloff KL, Nataro JP, Blackwelder WC, Nasrin D, Farag TH, Panchalingam S, Wu Y, Sow SO, Sur D, Breiman RF, Faruque AS, Zaidi AK, Saha D, Alonso PL, Tamboura B, Sanogo D, Onwuchekwa U, Manna B, Ramamurthy T, Kanungo S, Ochieng JB, Omore R, Oundo JO, Hossain A, Das SK, Ahmed S, Qureshi S, Quadri F, Adegbola RA, Antonio M, Hossain MJ, Akinsola A, Mandomando I, Nhampossa T, Acácio S, Biswas K, O’Reilly CE, Mintz ED, Berkeley LY, Muhsen K, Sommerfelt H, RobinsBrowne RM, Levine MM. Burden and aetiology of diarrhoeal disease in infants and young children in developing countries (The global enteric multicenter study, GEMS): a prospective, case-control study. Lancet. 2013 Jul 20;382(9888):209-22. doi: 10.1016/S0140-6736(13)60844-2, PMID 23680352.

9. Lanata CF, Fischer Walker CL, Olascoaga AC, Torres CX, Aryee MJ, Black RE, Child Health Epidemiology Reference Group of the World Health Organization and UNICEF. Global causes of diarrheal disease mortality in children $<5$ years of age: a systematic review. PLOS ONE. 2013;8(9):e72788. doi: 10.1371/journal.pone.0072788. PMID 24023773.

10. Walker CLF, Rudan I, Liu L, Nair H, Theodoratou E, Bhutta ZA, O’Brien KL, Campbell H, Black RE. Global burden of childhood pneumonia and diarrhoea. Lancet. $2013 \mathrm{Apr}$ 20;381(9875):1405-16. doi: 10.1016/S0140-6736(13)602226, PMID 23582727.

11. Vasco G, Trueba G, Atherton R, Calvopiña M, Cevallos W, Andrade T, Eguiguren M, Eisenberg JN. Identifying etiological agents causing diarrhea in low income Ecuadorian communities. Am J Trop Med Hyg. 2014 Sep;91(3):563-9. doi: 10.4269/ajtmh.13-0744, PMID 25048373.

12. Yu J, Jing H, Lai S, Xu W, Li M, Wu J, Liu W, Yuan Z, Chen Y, Zhao S, Wang X, Zhao Z, Ran L, Wu S, Klena JD, Feng L, Li F, Ye X, Qiu Y, Wang X, Yu H, Li Z, Yang W. Etiology of diarrhea among children under the age five in China: results from five-year surveillance. J Infect. 2015 Jul;71(1):19-27. doi: 10.1016/j.jinf.2015.03.001. PMID 25753104.

13. Taniuchi M, Sobuz SU, Begum S, Platts Mills JA, Liu J, Yang Z, Wang XQ, Petri WA Jr, Haque R, Houpt ER. Etiology of diarrhea in Bangladeshi infants in the first year of life analyzed using molecular methods. J Infect Dis. 2013 Dec 1;208(11):1794-802. doi: 10.1093/infdis/jit507, PMID 24041797.

14. Balemba OB, Bhattarai Y, Stenkamp Strahm C, Lesakit MS, Mawe GM. The traditional antidiarrheal remedy, Garcinia buchananii stem bark extract, inhibits propulsive motility and fast synaptic potentials in the guinea pig distal colon. Neurogastroenterol Motil. 2010 Dec;22(12):1332-9. doi: 10.1111/j.1365-2982.2010.01583.x. PMID 20718943.

15. Zhao SS, Ma DX, Zhu Y, Zhao JH, Zhang Y, Chen JQ, Sheng ZL. Antidiarrheal effect of bioactivity-guided fractions and bioactive components of pomegranate (Punica granatum L.) peels. Neurogastroenterol Motil. 2018 Jul;30(7):e13364. doi: 10.1111/nmo.13364, PMID 29717519.

16. Ojewole JA, Awe EO, Chiwororo WD. Antidiarrhoeal activity of Psidium guajava Linn. (Myrtaceae) aqueous leaf extract in rodents. J Smooth Muscle Res. 2008 Dec;44(6):195-207. doi: 10.1540/jsmr.44.195, PMID 19234374.

17. Bahekar SE, Kale RS. Antidiarrheal activity of ethanolic extract of Manihot esculenta crantz leaves in wistar rats. J Ayurveda Integr Med. 2015 Jan-Mar;6(1):35-40. doi: 10.4103/09759476.146542, PMID 25878462.

18. Okonkwo CJ, Njoku OU, Okonkwo TJN, Afieroho OE, Proksch P. Two new acylated flavonol glycosides from Mimosa pigra L. leaves sub-family Mimosoideae. Future J Pharm Sci. 2016 Dec 1;2(2):71-5. doi: 10.1016/j.fjps.2016.08.003.

19. Nguyen LNP, Nguyen Huu DM, Dang HP, Huynh NV, Dang PH. A new furanochromone from the leaves of Mimosa pigra. Nat Prod Res. 2021 Nov;35(21):3963-9. doi: 10.1080/14786419.2020.1752209, PMID 32308029.

20. Rakotomalala G, Agard C, Tonnerre P, Tesse A, Derbre S, Michalet S, Hamzaoui J, Rio M, Cario Toumaniantz C, Richomme P, Charreau B, Loirand G, Pacaud P. Extract from Mimosa pigra attenuates chronic experimental pulmonary hypertension. J Ethnopharmacol. 2013 Jun 21;148(1):106-16. doi: 10.1016/j.jep.2013.03.075. PMID 23583901.

21. Sonibare MA, Gbile ZO. Ethnobotanical survey of anti-asthmatic plants in South-Western Nigeria. Afr J Tradit Complement Altern Med. 2008 Jun 18;5(4):340-5. doi: 10.4314/ajtcam.v5i4.31288. PMID 20161955.

22. Rosado Vallado M, Brito Loeza W, Mena Rejon GJ, Quintero Marmol E, Flores Guido JS. Antimicrobial activity of fabaceae species used in yucatan traditional medicine. Fitoterapia. 2000 Sep;71(5):570-3. doi: 10.1016/s0367-326x(00)00200-8, PMID 11449511.

23. Akshaya S, bhuvaneshwari G, Grace JL, Vennila R. In vitro efficacy testing of neem (Azadirachta indica) extract against aerobic and anaerobic bacteria. Int J Curr Pharm Res. 2020 Nov 15:119-21.

24. Pradeep BV, Tejaswini M, Nishal P, Pardhu G, Shylaja S, Kumar KCh. Phytochemical screening and antimicrobial activities of plant extract of Lantana camara. J Environ Biol. 2013 May;34(3):645-9. PMID 24617153.

25. Diwakar Y, VC, Sharon SE. Study of parmelia perlata for its potential as an anti-inflammatory and antiarthritic agent using in vitro model. Asian J Pharm Clin Res 2019;12(1). doi: 10.22159/ajpcr.2019.v12i1.28479.

26. Ugwah Oguejiofor CJ, Okoli CO, Ugwah MO, Umaru ML, Ogbulie CS, Mshelia HE, Umar M, Njan AA. Acute and sub-acute toxicity of aqueous extract of aerial parts of Caralluma dalzielii N.E. Brown in mice and rats. Heliyon. 2019 Jan 29;5(1):e01179. doi: 10.1016/j.heliyon.2019.e01179, PMID 30775575.

27. De Zoysa MHN, Rathnayake H, Hewawasam RP, Wijayaratne WMDGB. Determination of in vitro antimicrobial activity of five Sri Lankan medicinal plants against selected human pathogenic bacteria. Int J Microbiol. 2019 May 6;2019:7431439. doi: 10.1155/2019/7431439, PMID 31198423.

28. Ateufack G, Nana Yousseu W, Dongmo Feudjio B, Fonkeng Sama L, Kuiate J, Kamanyi A. Antidiarrheal and in vitro antibacterial activities of leaves extracts of Hibiscus asper. hook. f.(malvaceae). Asian J Pharm Clin Res. 2014 Sep;7:130-6.

29. Zafar Imam M, Sultana S, Akter S. Antinociceptive, antidiarrheal, and neuropharmacological activities of Barringtonia acutangula. Pharm Biol. 2012 Sep;50(9):1078-84. doi: 10.3109/13880209.2012.656850, PMID 22830487. 
30. Wawruch M, Bozekova L Krcmery S, Kriska M. Risks of antibiotic treatment. Bratisl Lek Listy. 2002;103(7-8):270-5. PMID 12519001.

31. Sharma P, Vidyasagar G, Singh S, Ghule S, Kumar B. Antidiarrhoeal activity of leaf extract of Celosia argentea in experimentally induced diarrhoea in rats. J Adv Pharm Technol Res. 2010 Jan;1(1):41-8. PMID 22247831.

32. Tadesse E, Engidawork E, Nedi T, Mengistu G. Evaluation of the anti-diarrheal activity of the aqueous stem extract of Lantana camara Linn (Verbenaceae) in mice. BMC Complement Altern Med. 2017 Apr 4;17(1):190. doi: 10.1186/s12906-017-1696-1, PMID 28376868.

33. Nesa ML, Karim SMS, Api K, Sarker MMR, Islam MM, Kabir A, Sarker MK, Nahar K, Asadujjaman M, Munir MS. Screening of Baccaurea ramiflora (Lour.) extracts for cytotoxic, analgesic, anti-inflammatory, neuropharmacological and antidiarrheal activities. BMC Complement Altern Med. 2018 Jan 30;18(1):35. doi: 10.1186/s12906-018-2100-5, PMID 29378554.
34. Derebe D, Abdulwuhab M, Wubetu M, Mohammed F. Investigation of the antidiarrheal and antimicrobial activities of $80 \%$ methanolic leaf extract of Discopodium Penninervum (Hochst.). Evid Based Complement Alternat Med. 2018 Oct 4;2018:1360486. doi: 10.1155/2018/1360486, PMID 30402115.

35. Awad AB, Toczek J, Fink CS. Phytosterols decrease prostaglandin release in cultured P388D1/MAB macrophages Prostaglandins Leukot Essent Fatty Acids. 2004 Jun;70(6):51120. doi: 10.1016/j.plefa.2003.11.005. PMID 15120714.

36. Hämäläinen M, Nieminen R, Asmawi MZ, Vuorela P, Vapaatalo $\mathrm{H}$, Moilanen E. Effects of flavonoids on prostaglandin E2 production and on COX-2 and mPGES-1 expressions in activated macrophages. Planta Med. 2011 Sep;77(13):1504-11. doi: 10.1055/s-0030-1270762, PMID 21341175

37. Kaczmarek B. Tannic acid with antiviral and antibacterial activity as a promising component of biomaterials-a minireview. Materials (Basel). 2020 Jul 20;13(14):3224. doi: 10.3390/ma13143224, PMID 32698426 